\title{
THE SPATIAL TURN
}

a virada espacial

\author{
Ana Fani Alessandri Carlos *
}

\section{Resumo}

Do ponto de vista da geografia, o artigo desenha uma perspectiva teórico-metodológica de análise da realidade urbana, partir da centralidade da categoria "produção do espaço", como momento constitutivo do caminho que formula a chamada metageografia. Uma hipótese se desenvolve ao longo deste artigo: o processo de reprodução da sociedade se realiza, no mundo moderno, através da produção do espaço urbano. É através da produção do espaço que o capital se realiza apontando a constituição do urbano como negócio e inaugurando novas contradições ( sem deixar todavia de aprofundar outras), que estão no fundamento da luta pelo espaço da vida, iluminando um projeto de transformação orientado pela ideia do "direito à cidade".

Palavras-chave: Espaço urbano; Metageografia; Urbano como negócio; Direto à cidade.

\section{Abstract}

From the point of view of geography, this article outlines a theoretical-methodological perspective foranalyzing urban reality based on the centrality of the category of "space production" as a constitutive moment of the path that formulates the so-called metageography. One hypothesis is developed over the course of this paper: there production process of society takes place, in the modern world, through urban space production. It is through space production that capital is attained, thus pointing out the constitution of what is urban as a business and introducing new contradictions (without ceasing to intensify other ones), which are at the basis of the struggle for space in life. This shines light on a transformation project guided by the idea of the "right to the city".

Key words: Urban space; Metageography; Urban as a busness; Rights to the city.

\section{Resumen}

Desde una perspectiva de la geografía, el artículo dibuja un punto de vista teórico y metodológico de análisis de la realidad urbana, desde la centralidad de la categoría de "producción del espacio" como momento constitutivo de la manera que hace que la llamada metageografia. Una hipótesis se desarrolla a lo largo de este artículo: el proceso de reproducción de la sociedad se lleva a cabo en el mundo moderno a través de la producción del espacio urbano. Es a través de la producción del espacio que el capital se realiza apuntando a la constitución de la ciudad como un negocio y la apertura de nuevas contradicciones (sin dejar sin embargo profundizar otros), que son el fundamento de la lucha por la vida en el espacio, la iluminación de un proyecto de transformación guiada por la idea el "derecho a la ciudad".

Palabras clave: Espacio urbano; metageografia; urbano y de negocios; directo a la ciudad.

(*) Lecturer, Doctor of the State University of São Paulo (Universidade Estadual de São Paulo) - -Av. Lineu Prestes , 338, CEP: 05508900, São Paulo (SP), Brasil. Tel: (+55 11) 30913749 - anafanic@usp.br 


\section{INTRODUCTION}

This article begins with some observations. The first one (which may be obvious, though fundamental for establishing the foundations of the debate about the city and the urban in Geography today) is about the idea of there being various theoretical-methodological possibilities and paths for considering the world from the perspective of Geography. None of these paths is false, nor true, which indicates that the knowledge process takes place in the gathering and confrontation between different (theoretical-methodological) trends and views. We insist on this point because of the trend of homogenization that is being imposed on the university, proposing a single way of thinking and a single way of conducting research, with a focus on the empirical and the depreciation of theoretical thought. With respect to differences, they are presented as a condition for the dialogue between perspectives that, certainly, will not take place without immense difficulties, since it is difficult to recognize critique as inherent to the act of knowing. However, under a guise of prejudice, the debate becomes void, preventing Geography from moving forward. Nevertheless, the dialogue is presented with a sense of urgency given the need for debate and understanding the current urban crisis.

As a consequence of the observation above, the second regards the need to reflect on the meaning and role of Geography in the 21 st century, in its challenges of understanding the current reality. A first challenge concerns the disciplinary status of Geography, which, as a product of the division of labor in knowledge, suffers from exacerbated specialization. We know very well that, this way, we run the risk of producing (by fragmenting reality, without the whole as a foundation) ignorance. On the other hand, inundated by neoliberal thinking, the university lost the autonomy to think about the world, enclosed as it is in the law of efficiency and competitiveness as a final objective. Therefore, the time for reflection has become void, creating a set of quick papers, dissertations and theses presented in an incomplete way, which weakens our capacity to reflect on the modern world. This academic scenario recreates the interpretative models that immobilize dynamicity and make explicit the clarifying processes of the components of urbanization today.

A third observation, with respect to the protests that have been occurring in the global urban panorama, is that they shed light on a possible frame of reference that enables a reflection on the urban crisis, placing the dialectic at the heart of the issue. In Brazil, the so-called "workshops of June 2013", whose initial theme was public transportation (price, quality, inefficiency), challenged public authorities and researchers. They brought up much more complex questions than mobility, highlighting the dynamic of urban production in its socio-spatial components. It is possible to understand them as a struggle in the city for the city, which changes the terms of the issue. This is because, on the one hand, they signal a question about the direction of public policies that promote the establishment of the urban as a business - based on the alliances between the public and private spheres openly contrary to the interests of society. On the other, they reveal segregation and, with it, the awareness of depriving some of the city. Therefore, the aforementioned protests evidence an urban production in which access to the city, as a place to live, is strongly characterized by segregation, which, in turn, is founded on an inequality that emerged historically and which produced the private appropriation of social wealth. This overview points towards the fundamental contradiction of the production of space: its social production versus its private appropriation. The contradiction, assumed in the establishment of capitalist society, develops due to the production of property as an abstraction, in its private dimension, as well as in its legal form at the foundation of the capitalist production of space.

As such, we can consider the movements (which characterize urban life, particularly metropolitan life), the protests on the streets question that which is at the basis of our society: the differential appropriation of wealth, inequality always being reinstated with the development of capitalism, the commodification of the world, political alliances aimed at capital accumulation, the abuse of power and, fundamentally, the expulsion of a significant portion of society from the public sphere. From this perspective, they question the logic of growth and the rationale of the means of production, as 
the reproduction of social relations dominated by the market. They emerge as a struggle for living space, for a democratic space where they can express themselves and decide on a common destiny. Therefore, they allow us to bring up to date the debate on alienation, by confronting the city as a construction site with the subjects that built it.

\section{A POSSIBLE PATH}

Metageography is the name of the analysis that we have been building over the past few decades with critical effort in relation to the Geography that we study. It is not about creating another Geography, but about the need to overcome the fragmentations imposed by the geographical studies that define "many geographies", in which researchers can divide the reality studied, as well as making the levels of analysis (economic, cultural) autonomous.

Therefore, we present the following question: How can Geography produce a way of thinking that explains reality as a whole (shedding light on the contradictions of the modern world as a foundation of conflicts experienced in the city, revealing the highly unequal society in which we live), replacing disciplinary division?

Our path intends to develop an understanding of urban reality through the centrality of the notion of "space production", which results from the assumption that the production of space is inherent to living life and, therefore, social relations have a demand for space and time. In sum, this means that the materialization of the spatial process takes place in everyday life by establishing social relations that produce places. Man appropriates the world, through the appropriation of space, in all of its senses and its body, giving space a double dimension. On the one hand, it means locating activities and human actions constitutive of life; on the other, it includes in its nature, a social component given by the social relations that are carried out in a determined space-time, which is the reproduction of society. This perspective clarifies the role of the city as a human construction, a materiality produced over the course of history, location and product, throughout its constant reproduction, which therefore enables us to see space as a product of humanity. Therefore, among the human activities that produce the world and history, one of them produces space. That is, the production of life/production of space constitute a historical relation and emerge as a civilizing moment, hence, the inextricability of the production of man and the production of space.

Here, we propose a shift in the analysis. We move away from the simple understanding of the distribution of the activities of men/human groups throughout space, towards the social production of space as a moment of the production of life.

The production of space thus allows us to replace the idea of space as a stage for human action, enabling an understanding of the social dimension of space produced for a society distinguished by classes. The active role of a society that builds an objective world in practice, which can be characterized as socio-spatial, points to the reproduction of social relations as a space-time relation. Space thought of as a production/product of the action of society is thus entirely immersed in social reproduction. This change in thought gives us a glimpse of the role of the production of space in the reproduction of contemporary society. This analytical shift implies rethinking categories of urban analysis, such as: urban land income, urban environment, segregation, etc.

In the capitalist economic system, the production process makes space itself a commodity, (with characteristics, different from those of the classic commodity). As such, space is subject to the law of the value that qualifies it as a use value and exchange value, with its access conditional upon the existence of property and the dynamics of the market. Within the scope of the exchange value, the production of space is subject to the logic of ownership, which is established at the moment of private appropriation of portions of the city (the expression of this production), of which one may be an exclusive sphere of a private nature, excluding all other possibilities (which, in its various forms, is the foundation of wealth). This action establishes and makes human existence possible and takes place as a process of the reproduction of life through the process of appropriating the world. The 
urban space reproduced in the modern world, under the guidance of the exchange value, positions the citizens in the city, limiting and determining their everyday lives. This guidance conflicts with the use value and use as a dimension of living human life. It is a necessary step to understanding the social conflicts that manifest as a struggle for housing, public transportation, urban infrastructure, green areas, etc. In space, however, conflicts are revealed, relations of inequality are maintained and broadened, as can be seen in the city and in urban life in its broad dimensions and scales.

On this theoretical path, the following are replaced: a) the phenomenon level (though without eliminating it), aiming to understand, in depth, the contradictory dynamic behind the "new appearances" that characterize the urban landscape and the world of images and ideologies that are scattered throughout everyday life; $b$ ) the absolute materiality of space imposed by the idea of organizing activities in the territory shedding light on the objectivity/subjectivity relation; c) the naturalization of social processes towards the social components of the production of space, revealing the productive strength of capital in the production/reproduction of space in its practical dimension; d) the ideologies that sustain the "welfare" society, reducing subjects to their status as a consumer in the growing pursuit of new products, in renewed spaces. Therefore, this perspective presents, as a consequence, questions about the world in which we live and a pursuit of the residual forces present in the urban, that act to change it. The path pointed out here indicates the need to replace the ontological dimension of space, though it is not about having an epistemological debate, but about directing knowledge towards the production/reproduction of space as a level of social reality. One of the hypotheses suggests that in space one can see the concrete possibilities of accomplishing the transformation of the current society. Metageography, thus associating theory and practice, deals with the elements that form the basis of praxis. In this sense, urban life sheds light on the sphere of everyday life, where atomization, while it is the super-organization of life, is also a field of voluntary and planned self-regulation, imposed, without resistance, through a strongly bureaucratized order, by means of imperceptible repressions and pressures. This situation still brings with it, dialectically, that which denies this logic.

\section{CONTRADICTIONS OF SPACE}

Praxis is revealed to be contradictory, that is, the contradiction between the social production of space and its private appropriation is at the basis of understanding spatial reproduction, which determines all moments of life. The production of space is subject to the capitalist logic that turns it into a commodity, subsuming life. The production of space as a commodity is increasingly linked to the commodity form, serving the needs of accumulation, through the metamorphoses of uses and functions of places that are also reproduced under the law of the reproducible, based on the strategies of reproduction (at each moment in the history of capitalism).

In its development, capitalism has spread throughout the planet, creating a global space, stimulating new sectors of activities as an extension of productive activities. From this situation, we can observe the two following processes: on the one hand, space produced as a commodity enters the exchange circuit, to the extent in which all social and economic activities require the use of space as a condition of appropriation. So, it is fragmented and portions of the city are sold for reproduction.

In this sense, space emerges as a condition of social and economic production. But, on the other hand, space is the means for its completion and, therefore, its product. From the point of view of accumulation, urban space becomes a location and support for the social relations of production (and ownership). However, at its foundation is the condition and means of establishing the capital turnover cycle, constantly recreating places favorable for moments of production, distribution, circulation, exchange and consumption of commodities - material as well as immaterial - as an ever-increasing possibility of the realization of capital. In this movement, places are designed as those with the necessary infrastructure for carrying out each specific activity, such that one can see a favorable equation for the realization of profit. But, each fraction of capital acts according to its 
own logic (either countering or associating it) to quickly fulfill its purpose - continued accumulation. Flowing and Fixed, materiality and movement, the process is established by the uninterrupted passage of one moment to another of the capital turnover cycle (which, by turning over, realizes capital as a valuation process), at the same time in which it brings together and associates individual capital cycles. Far from being blind development, the aforementioned process is sustained through precise strategies.

Today, capital moves at a different pace in space, since investments migrate quickly from one sector of the economy to another in pursuit of profit, at a time of productive restructuring. At the same time, a portion becomes merely speculative capital, with autonomy in relation to the productive sphere. We defend the thesis that the reality of this 21 st century points towards the importance of the reproduction of urban space as a necessary condition for accumulation, in the move from the hegemony of industrial capital to financial capital. The current moment reveals the move from the production of space as a condition among conditions of capital accumulation - based on the classic production of commodities - to the production of space itself as a condition of the current reproduction in the face of the crisis of accumulation (without, however, eliminating the former moment). Consequently, the fact that the contradictions of the modern world are clarified as contradictions of the reproduction of urban space as a product of the reproduction of capital.

This process shows that capitalist accumulation takes place, based on production, for the whole city, being consolidated as a spatial extension, producing the city as a commodity. This means to say that, in this century, this production has been acquiring a new meaning, since the crisis of the productive process requires the development of new productive sectors, enabling the shift of capital to more productive spheres. This has been occurring with the spatial abandonment/redirection of classical production - that of the means of production or consumer goods - to the production of urban space - portions of the city or the whole city - as a moment of realizing accumulation. As such, the production of urban space fulfills this process, which means to say that, faced with the internal contradictions of capitalism in relation to the tendency of the rate of profit to fall, the pursuit of realizing added value shifts fundamentally to the production of space. Therefore, urbanization emerges as a strategic moment of the reproduction of capital due to the opening up of new possibilities of capital valuation.

In this new phase, there are new possibilities for occupying space, which explains the emergence of a new logic associated to a new form of dominating space, which is reproduced, ordering and guiding occupation, fragmenting and making spaces exchangeable based on operations that are made in the market. Therefore, space is produced and reproduced as a reproducible commodity, whose production/reproduction takes place under the scope of exchange value (perceivable in the case of urban operations).

This fact can be observed through the development and expansion of new economic activities that have gained importance in terms of orientation of investments for leisure and tourism, which requires the diversification of tertiary activities (new constructions and urban infrastructure) with the broadening of the role of the real estate sector in the urban economy. We see an expansion, in the urban fabric as well as in the migration of industrial establishments, substituted (in their location) by the construction of shopping centers, the creation of gated communities, as well as the reproduction of entire areas aimed at culture and leisure in major cities. On the level of places, financial capital, which is appropriated from space for making productive investments supported in the real estate sector, constantly produces (allied to the construction industry) space as a consumable commodity - no longer only for the realization of the capital cycle of commodities, but as a moment of capital production. The reproduction of relations in and through space imposes the private interests of various economic sectors of society, for whom there is the condition of accomplishing economic production in space.

In this process, the reproduction of urban space signals the move from use and use value to the imperative of exchange value as a necessary moment of capitalist accumulation, which guides 
the forms of intervention in the city, as well as redefines a way of thinking about it and managing it, based on new strategies. Therefore, public policies are elaborated as producers/reproducers of space, aimed at its economic function and indicating, consequently, the devaluation of spaces for use, of the view of the city as a creative force, of space as a place of culture, etc. There is, then, the juxtaposition of various levels of reality as distinct moments of the general reproduction of society, such as that of political domination, the accumulation of capital and carrying on with (the political, economic, social and cultural) life. So, if space corresponds to a global reality, revealing it on the level of the abstract (the level of knowledge), its social production refers to a socio-spatial practice, connecting it to the concrete level and shedding light on an association between scales that intersect, juxtaposed on the level of places.

This analysis also involves, in conjunction, three scalar levels: the level of global space, shedding light on the virtuality of its continuous reproduction, producing a global space and an urban society; the level of places, that of living life in the acts of everyday life as a means of appropriation, which is realized by use, through the body; the level of the metropolis, which acts as a mediation between the two other levels.

\section{THE ROLE OF SPACE IN UNDERSTANDING THE CONTEMPORARY URBAN REALITY}

The level of the investigation points to the constitution of an urban reality that is generalized in the modern world, not because the urban population replaced the rural population, but because the social dynamic is defined as urban in the intensifying globalization process. In its entirety, this urban clarifies the establishment of a spatial problem, which clarifies urban reality, revealing the production of space as a moment necessary for the reproduction of the capitalist society, in which the production of the city itself is established as a commodity sold on the global market. At the same time, it produces a new way of life based on a new urbanity, by creating new technical objects that mediate social relations, redefining the forms of appropriating space in the city, imprisoning the body, creating concrete barriers to socio-spatial mobility. In its objectivity, it points to a reality subject to the norm that organizes and guides the expanded creation of the production of commodities and life, dominating work process and, based on this, subsuming all social relations (in and out of production, dominating the class structure of society and defining contracts), given that the logic that guides the valuation process continually produces everyday life.

In space, the orientation and changes in the forms, structures and functions of places bring with them transformations in the use of and access to the city by its citizens, beyond the productive sphere. In this sense, the concrete dimension of the production of space (which includes, but is not restricted to the purely material production of space) demonstrates non-absolute objectivity. Reality as a reproduction of social relations, under the guidance of the relentless expansion of the capitalist process, upon incorporating the production of space into everyday life, sheds light on distinct strategies and projects. In this state, urban space is reproduced as a possibility of realizing the capital cycle of commodity production as well as the raw material for achieving financial capital, through the productive consumption of space. This production requires the creation of public policies (as a form of spatial intervention), to direct the budget and construction of urban infrastructure to the locations chosen by the productive sector. In turn, the real estate sector and its focus on the production of space as a form of accumulation influences public policies through lobbies and alliances. Characterized by the action of real estate promoters in consonance with the strategies of the financial system, end up steering the political administration and reorganizing the process of spatial reproduction. With this, the action of the State - through local authorities that intervene in the production process of the city - reinforces the hierarchy of places, creating new centralities. 


\section{URBANIZATION AS A BUSINESS}

At this point, a new problem is presented, which guides this research: the reproduction of commodities and of their world, which feeds off of the production of urban space (the city and its scope), as well as the social relations defined on the level of everyday life (programmed consumption in a standardized society) as a moment of urban society in which accumulation shifts from the productive sphere in the heart of the industry to that of the city and its extensions, which means that its production becomes a moment of the process of capital valuation. At this point, the exchange value is imposed more clearly over the use value in the production of urban space. This strategy put into effect by accumulation promotes: a) the sale of natural or historical characteristics of places for the production of the tourist and leisure market; b) the construction of gated communities on the outskirts of the city, as a moment of reproduction in the real estate sector; c) the creation of public policies aimed at the reproduction of space. The real estate market gains centrality, mainly in major cities, with the verticalization of areas of expansion in the historical center, with the construction of residential buildings aimed at the middle/high income or corporate market, cultural centers, museums, shopping centers, etc. The policies for revitalizing rundown areas (from the point of view of the market) aim to reintroduce them to the valuation circuit, as a moment of reproduction of space. This strategy forces out sections of society that use these places for housing or for socializing in various and distinct groups.

In contemporary times, society dominated by the economy and by the need for accumulation, is established in the production of a globalized space as a trend and moment of developing capitalism, highlighting that the need to overcome moments of crisis occurs by incorporating new productions into the accumulation process, among them urban space, which is achieved with the hegemony of financial capital. The "production of the city as a business" is situated in this context, revealing a specific characteristic of contemporary urbanization, a moment in which space emerges as a necessary condition for the reproduction of capital, that is, the moment in which capital can only be realized through the strategy that makes space a moment of the productive process.

At this time, the reproduction of the metropolis is a necessary condition for the reproduction of capital. Here, it is about capital being established in the specific production of space in the form of a real estate enterprise, whether for offices, or social housing, cultural centers, shopping centers, and gated communities. As a social production, its realization is part of the nucleus of the accumulation process, which, in its financial form, is achieved preferably through opening places for new private businesses in renewed areas. The terms of this reproduction is made clear by establishing a globalized space with the development of capitalism, overcoming moments of crisis of accumulation and pointing out the role of space in the production/reproduction of capital.

This process indicates that economic reproduction occurs by means of spatial production at a time in which money is valued in the financial sphere, being associated to other factions of capital, and so restoring the unity necessary for carrying out the real process of accumulation, as a moment of the production of "a new space" in the metropolis. Therefore, the meaning and role of space is transformed, translating into a new horizon of valuation. A new fact is revealed: the generalization of the distribution of added value created in the production of local spaces, achieved on the international level by linking sectors aimed at businesses "of urban land". Therefore, capitalism transforms historical conditions, with the purpose of reproducing those whose terms are made clear in the reproduction of a globalized space as a need for overcoming moments of crisis of accumulation.

The dominated urban space serves the reproduction of social relations of production and is imposed on everyone, constantly reestablishing the continuity of the valuation cycle and, with it, the structure of life. The reproduction of space brings with it a new movement of expropriation, since the action that reproduces these places is achieved by substituting one social class for another with greater purchasing power. This is a consequence of the actions that promote the valuation of 
urban land, resulting in the lower income classes being moved towards the peripheries, which are increasingly farther away from their old homes, their jobs and from places of social interaction. As a result, this promotes unemployment, disrupts family structures, separates activities, breaks up social relations, and deprives people of their references (which sustain life).

\section{THE LEVEL OF PLACES AND EVERYDAY LIFE}

Encroached upon by determinations that stray from the place, everyday life carries on as a planned order of space and time, between the irreversible metamorphosis of space and the residues that persist, between use and exchange, within the scope of the exchange value, to homogenize life. This logic recreates life and tends to destroy and remove history and identity. An urbanity founded on the symbols of consumption redefines social relations. It is not only about new technical objects, but also about a strong media structure. What moves the world, however, is the ever-increasing possibility of social relations that constitute it are reproduced (under the logic of capital) as a whole, replacing the economic sphere to dominate all levels of reality, encompassing the reproduction of the entire society as a need to broaden the social base of consumption; a consumption that is no longer linked to classic commodities. The segmentation of the activities of man, massacred by the process of homogenization, subject to the logic of accumulation, to the language and symbols of the commodity, creates the basis for the development of its universal condition as a consumer. In space, social inequality is expressed as segregation, which is the most complete product of the existence/concentration of ownership and wealth, pointing to the production of alienated space, established in everyday practice - urbanization is expressed in all of its violence. On the social level, the reproduction of urban space takes effect as a source of deprivation: that of the subject deprived of the conditions of life, in its creative possibilities and in its alterity. The situation results from reproduction guided by the exchange value that goes up against use. As such, the reproduction of urban space, under the logic of capitalist accumulation, replaces the conditions that form its foundation: the inequality of individuals in society experienced concretely through the different means of appropriation, founded on private ownership in its various forms.

According to the notion by Sève (2008, p. 560), we are living in a moment in which the "self-proclaimed gestational [capital] of the planet gives free rein to the constitutive trend: the unrestrained subordination of human subjects to their majesty, the profit rate. In an aphorism that moves us as much today, as it did yesterday, Marx wrote, in 1844, that the depreciation of the world of men increased in direct relation to the world of things."

\section{AMNESIC SPACE}

Urban space is today, and has always been, over the course of its history of production, a condition, means and product of reproducing social relations. It is a production that involves and has as its subject society as a whole. In the modern world, faced with forms that metamorphose increasingly quickly, the references that characterize and sustain life in the city are modified constantly and the history accumulated there loses its deeper meaning, faced with the need for accumulation of capital. The constant renewal - transformation of urban space through morphological changes - produces constant transformations in the urban times of life, in the ways and times of appropriation/use of public and private spaces. Places transform irreversibly with the simplification of the history contained in them, making them equal to many others, placing society in direct relation to a space deprived of memory (as a product of the constitution of an identity revealed by a history experienced as a socio-spatial practice).

The marks of a life of relations and references of life fade away in the city, in many cases, lost forever. Changes in the use of space subject to a new organization of time in everyday life place the individual in unexpected changing situations (at an increasingly fast pace), provoking "alienation" 
(the way in which we experience modernity). The world of abstraction, which coincides with the destruction of urban references for supporting life, which constitute the urban identity, have come to dominate all social relations. In this context, the reproduction of urban space creates a new space-time relation in which amnesic space is directly related to an ephemeral time.

But, dialectically, as use, everyday life is a field of spontaneity, that which escapes and is opposed to this world of commodities and images. It is the place in which one can overcome the alienations that envelop it and make explicit the struggles in the city, for the city.

\section{FINAL CONSIDERATIONS}

The analyses about our "post-modern condition" are centered today particularly on the transformations of time and culture, building an a-spatial understanding of reality, which goes against the fact - for example - that the occupation of public spaces, around the world, as a place for protesting and exercising denied citizenship, has insistently pointed towards a struggle for space, in carrying on with everyday life, as well as that which establishes the public sphere in its possibilities. With this reasoning, if the places of policy and culture, despite not being insignificant for understanding the whole, are insufficient, requiring a consideration of the space-time dynamic.

The social movements that have been taking place on the political scene signal an awareness of the "deprivation" and, therefore, their understanding cannot be limited to the sphere of the goods necessary for living life, given that they indicate the scale of the achievement of desires to create a project capable of opening up to the construction of another society.

Struggles emerge in intervals of everyday life as an awareness of the inequalities experienced on various levels. Therefore, resistances do not point towards a single meaning, but bring together various perspectives (flags) in which inequality takes place and the deprivation that constitutes urban life. By coming together, the movements question that which forms the basis of our society: the differentiated appropriation of wealth, inequality, the violations of power, the narrowing of the public sphere. They move in the sense of questioning the logic of growth and the political alliances that are made against the social. They emerge as a struggle for space, for a democratic space where they can express themselves and determine their destinies. The struggles introduce and demand democratic practices, putting on the negotiating table the interests of society as a whole, against the interests of businessmen, representatives of groups whose goal is profit, whether in the directly productive sectors or on the level of investments and speculation.

Therefore, the protests in public spaces - cited at the beginning of this article - break out in everyday life, pointing out the existence of latent residues in this society. By being defined by the denial of the urban experience, the struggles place the "right to the city" at the heart of the debate. Though poorly defined, the "right to the city" as a concept requires a profound reflection. In the terms expressed by Henri Lefebvre $(1968,1970)$, the achievement of the right to the city brings with it the demand of questioning the entire society subject to the economy and politics, manifest as a superior form of rights, on the same level as the right to freedom, to individuality in socializing; the right to construction (participating activity) and the right to appropriation, fully revealing use. With this guideline, it is possible to understand the "right to the city" as a practical need to overcome the spatial contradiction, use value/exchange value, that reigns in our society producer of commodities. Therefore, this right will only be resolved in overcoming that which is at the foundation of capitalism. A utopic project and not a public policy, the right to the city points to the need for theory and practice.

\section{BIBLIOGRAPHIC REFERENCE}

ARANTES, Paulo. O novo tempo do mundo. São Paulo: Boitempo, 2014

ARENDT, Hannah. A condição Humana, 10ª edição. Rio de Janeiro: Editora Forense Universitária, 2007. 
BENJAMIN, Walter. Paris, capital do século XIX. In: Walter Benjamin, Sociologia. São Paulo: Ática, 1985. BERNARD, Michel. Le corps. Paris: Éditions du Seuil, 1995.

BENSADID, D. Cambiar el mundo. Madrid: Catarata, 2004.

CARLOS, A. F. A. Espaço-tempo na metrópole. São Paulo: Contexto, 2001.

CARlOS, A. F. A. A condição espacial. São Paulo: Contexto, 2011.

CARLOS, A. F. A. Metageografia. In: Crise Urbana. São Paulo: Contexto, 2015, pp 9-24

CARLOS, A. F. A. A reprodução do espaço urbano. In: Crise Urbana. São Paulo: Contexto, 2015, pp. 25-35

CARLOS, A. F. A. A tragédia urbana. In: A cidade como negócio. São Paulo: Ed. Contexto, 2015, pp. 43-64

CHOMBARD DE LOWE, Paul-Henry. La fin des villes. Paris: Calmann-Lévy, 1982.

DEBORD, Guy. La societé du spectacle, $2^{\text {a }}$ edicion. Paris: Folio, 1992.

FILLIEULLE, Olivier; TRATTAKOWSKY, Danielle. La manifestation. Paris: La Presse Fond. Sc. Po, 2008.

HARVEY, D. El nuevo imperialismo. Madrid: Ediciones Akal, 2004.

HARVEY, D. Le capitalisme contre le droit à la ville. Paris: Éditions Amsterdan, 2011

HARVEY, D. Ciudades Rebeldes. Madrid: Ediciones Aykal, 2013

HALSTON, James. Cidadania Insurgente. São Paulo: Cia das Letras, 2013

HORKHEIMER, Max. Eclipse da razão. Rio de Janeiro: Labor do Brasil, 1976.

JAPP, Anselm. O reino da contemplação passiva. In: Muito Além do espetáculo, Adauto Nonvaes, São Paulo : Editora SENAC, 2004.

JUDENSNAIDER, E ert alli, Vinte Centavos: a luta contra o aumento. São Paulo: Vente, 2013

LEFEBVRE, Henri. Critique à la vie quotidienne. Paris: L'Arche,1961.

HARVEY, D. La production de l'espace, $3^{\mathrm{a}}$ edição. Paris: Éditions Anthropos, 1986.

HARVEY, D. Le droit à la ville. Paris: Anthropos, 1968.

LIPOVETSKY, Gilles. Espace privé, espace public à l'âge postmoderne. In: BAUDRILLARD, Jean et al. Citoyenneté et urbanité. Paris: Éditions Esprit, 1991. p. 105-122.

MARCUSE, P. La justice spatiale: résultante et cause de la justice sociale. In: BRET, B., GERVAIS-LAMBONY, P., HANCOCK, C., LANDY, F. (coord.). Justice et injustices spatiales. Paris: Presses Universitaires de Paris Ouest, 2010, p.75-92.

MARTINS, José de Souza. A sociabilidade do homem simples. São Paulo: Contexto, 2010.

PINTAUDI, Silvana. Poder político e controle do espaço. In: Anais do XII Colóquio Internacional de Geocritica, Universitat de Barcelona, "El control del espacio, espacio del control: acessível em http:/www. ub.edu/geocrit/coloquio2014/Silvana\%20Maria\%20Pintaudi.pdf, acessado em 20 de maio de 2015.

SÈVE, Lucien. L'homme la dispute. Paris: 2008

SMITH, Neil. Contornos de uma política espacializada: veículos dos sem-teto e a produção da escala geográfica. In: ARANTES, Antônio A. (Org.). O espaço da diferença. São Paulo: Papirus, 2000.

SOJA, E. La ville et justice spatiale. In: BRET, B.; GERVAIS-LAMBONY, P.; HANCOCK, C.; LANDY, F. (coord.). Justice et injustices spatiales. Paris: Presses Univ. de Paris Ouest, 2010 p. 55-73.

VILLAÇA, F. As ilusões do Plano Diretor, mimeografado, São Paulo: Agosto de 2005.

Submitted december 2015

Accepted january 2016 